Simbiosis Mutualisme Perpustakaan dengan Media Cetak sebagai Upaya Membudayakan Membaca dan Menulis bagi Masyrakat Muhammad Rohmadi

- Faktor Pengembangan dan Isu dalam Masalah Karier Pustakawan Masriyatun

Menguak Informasi via Alexa.com sebagai Evaluasi Menuju Optimalisasi

- Keberaksesan terhadap Perpustakaan dan Institusinya Wiji Suwarno

Profesionalisme Pustakawan dalam Layanan Informasi SriAnawati

Public Space dan Private Space: Posisi Strategis Perpustakaan dalam Mendukung

Pembelajaran Kolaboratif Purwani Istiana

Mewujudkan World-class Professionalism of Librarians di Era Library Mobile

Yuni Nurjanah

- Tantangan dan Kesiapan Pustakawan di Era Digital Dian Hapsari

Formulasi Strategi Membangun Eksistensi Perpustakaan Perguruan Tinggi

(Studi UPT Perpustakaan UNS Tahun 2015) RiahWiratningsih

Optimalisasi Perpustakaan Desa dalam Rangka Meningkatkan Pendidikan Masyarakat Bambang Hemanto

Optimalisasi Layanan Perpustakaan Perguruan Tinggi melalui Pemanfaatan Social

- Media Networking sebagai Media Komunikasi antara Perpustakaan dan Pemustaka Haryanto

Rekonstruksi Budaya Hukum Masyarakat dalam Pemulihan Pascakonflik Etnis Madura dan Melayu di Kabupaten Sambas 


\section{Jurnal \\ Pustaka Ilmiah \\ Jurnal Ilmiah UPT Perpustakaan UNS}

Jurnal Pustaka Ilmiah (JPI) sebagai media kreasi para pustakawan, guru, dosen, dan praktisi dalam pengembangan profesi secara berkelanjutan. Berbagai ide dan gagasan kreatif menjadi bahan kajian yang diimplementasikan dalam berbagai model pengembangan bahan pustaka, baik cetak maupun online. Kreativitas menjadi akar pengembangan ilmu pengetahuan sepanjang hayat dengan berbagai model pengembangan budaya literasi di perpustakaan. Keindahan dan kecermatan dalam sebuah tulisan ilmiah dan nonilmiah akan dapat direalisasikan secara nyata oleh sumber daya manusia untuk menghasilkan SDM yang unggul dan kreatif dengan membaca dan menulis untuk menyinari dunia. Budaya literasi menjadi upaya untuk pengembangan dan pemberdayaan perpustakaan sebagai pusat sumber belajar untuk mendukung tri dharma perguruan tinggi.

\section{SUSUNAN REDAKSI JURNAL PUSTAKA ILMIAH UPT PERPUSTAKAAN UNS}

Penanggung Jawab

Ketua Redaksi

Wakil Redaksi

Sekretaris

Penyunting Ahli
: Dr. Muhammad Rohmadi, M.Hum.

: Dra. Tri Hardiningtyas, M.Si.

: Haryanto, M.IP.

: Bambang Hermanto, S.Pd., M.IP., Henny Perwitosari, A.Md.

: 1. Dr. Muhammad Rohmadi, M.Hum. (Universitas Sebelas Maret);

2. Drs. Widodo, M.Soc.Sc. (Universitas Sebelas Maret);

3. Drs. Harmawan, M.Lib. (Universitas Sebelas Maret).

: Daryono, S.Sos., M.IP.; RiahWiratningsih, S.S., M.Si., Dinar Puspita Dewi, S.Sos., M.IP.; Sri Utari, S.E.

: Nurul H., A. Md.; Novi Tri Astuti, A.Md.

: Aji Hartono, A. Md.; Agus Sriyono, A.Md.; Aris Suprihadi, S.IP.

\section{DITERBITKAN OLEH UPT PERPUSTAKAAN UNS}

REDAKSI JURNAL PUSTAKA ILMIAH

Alamat: Jl. Ir. Sutami 36A Kentingan, Surakarta 57126

Telp./Fax.: (0271) 654311; email: jurnal.pustaka.ilmiah@gmail.com 


\section{PENGANTAR REDAKSI}

Salam pustaka. Dengan rasa syukur kepada allah swt. Segenap redaksi Jurnal Pustaka Ilmiah (JPI) mengucapkan banyak terima kasih kepada para penulis yang telah berkontribusi untuk penerbitan perdana JPI. Dengan terbitnya JPI ini berarti UPT Perpustakaan UNS telah memiliki media penulisan bagai para pustakawan, dosen, tenaga kependidikan, guru, dan praktisi untuk menuangkan ide dan gagasan kreatifnya secara tertulis.

Dalam penerbitan JPI perdana ini disajikan sepuluh tulisan antara lain: (1) Faktor Pengembangan dan Isu Dalam Masalah Karier Pustakawan (Masriyatun), (2) Menguak Informasi via Alexa.com sebagai Evaluasi Menuju Optimalisasi Keberaksesan terhadap Perpustakaan dan Institusinya (Wiji Suwarno), (3) Profesionalisme Pustakawan dalam Layanan Informasi (Sri Anawati), (4) Public Space dan Private Space: Posisi Strategis Perpustakaan dalam Mendukung Pembelajaran Kolaboratif (Purwani Istiana), (5) Mewujudkan World-class Professionalism of Librarians di Era Library Mobile (Yuni Nurjanah), (6) Tantangan dan Kesiapan Pustakawan di Era Digital (Dian Hapsari), (7) Formulasi Strategi Membangun Eksistensi Perpustakaan Perguruan Tinggi (Studi UPT Perpustakaan UNS Tahun 2015) (Riah Wiratningsih), (8) Optimalisasi Perpustakaan Desa dalam Rangka Meningkatkan Pendidikan Masyarakat (Bambang Hemanto), (9) Optimalisasi Layanan Perpustakaan Perguruan Tinggi melalui Pemanfaatan Social Media Networking sebagai Media Komunikasi antara Perpustakaan dan Pemustaka (Haryanto).

Akhirnya, redaksi JPI mengucapkan banyak terima kasih kepada Kepala UPT Perpustakaan UNS yang telah memberikan dukungan dan memfasilitasi untuk penerbitan JPI. Selain itu, ucapan terima kasih juga disampaikan kepada para penulis, tim redaksi, dan Yuma Pressindo, yang telah mempersiapkan dari awal sampai terbitnya JPI.

Desember 2015

Ketua Redaksi, 


\section{SAMBUTAN}

Dr. Muhammad Rohmadi, M.Hum.

Kepala UPT Perpustakaan UNS

\section{“Jadikalah tulisanmu sebagai cermin kehidupanmu di masa sekarang dan masa depan"}

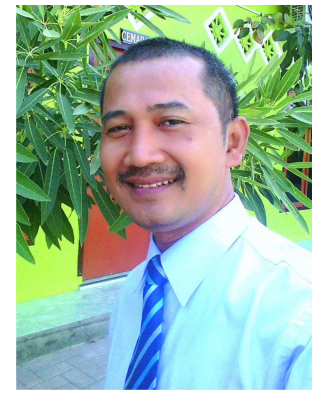

Selamat dan sukses atas diterbitkannya Jurnal Pustaka Ilmiah (selanjutnya disingkat JPI). Sambutan ini diberikan dalam rangka penerbitan perdana JPI. Jurnal ini sebagai media kreativitas dan pengembangan softskill para pustakawan, guru, dosen, dan praktisi untuk menuangkan ide dan gagasan dalam berbagai konteks kehidupan. Berbagai isu terkait dengan pengembangan perpustakan, pusat sumber belajar, pendidikan, dan budaya literasi akan menjadi topik-topik yang disajikan dalama jurnal ilmiah ini.

Diterbitkannya JPI sebagai bukti kepedulian UPT perpustakaan Ilmiah dalam rangka turut berpartisipasi untuk mengembangkan dan membudayakan literasi untuk para pustakawan dan civitas akademika di UNS dan luar UNS. Berbagai model pengembangan softskill menjadi alaternatif untuk membekali dan memperkuat jaringan kerja sama penulisan antarkelembagaan. Dengan demikian, kerja sama antarpustakawan dan pemustaka dapat diwujudkan dengan berbagai model dalam bidang literasi.

Penerbitan JPI sebagai upaya untuk memotivasi semua pustakawan menulis, baik ilmiah maupun nonilmiah. Para pustakawan harus menjadi pionir dalam bidang penulisan. Hal ini sebagai bentuk kepedulian dan keteladaan para pustakawan yang memproses, menyajikan, dan menikmati bahanbahan pustaka cetak dan noncetak di perpustakaan. Ketersedian bahan pustaka akan menjadi bahan paling nyata untuk dikembangkan dalam berbagai model perwujudan teknik peniulisan. Hal terpenting yang harus dimiliki oleh para pustakawan adalah semangat untuk berbagai pengetahuan melalui tulisan.

Kepedulian setiap sumber daya manusia kepada kelembagaan dapat dituangkan dalam berbagai model pengabdian, salah satunya adalah melalui tulisan. Berbagai ide dan gagasan dapat direalisasikan dengan berbagai model bentuk artikel jurnal, buku, modul, monograf, dan lain sebagainya. Para civitas akademika, guru, praktisi harus memiliki keterampilan menulis sebagai bentuk perwujudan pengembangan diri secara berkelanjutan. Berbagai tulisan dan referensi sudah disajikan tetapi masih sangat minim untuk diimplementasikan dalam kehidupan. Banyak orang pandai dalam berbicara tetapi masih sedikit yang menuangkan ide dan gagasannya dalam bentuk tulisan.

Akhirnya, keluarga besarUPT Perpustakaan UNS mengucapkan banyak terima kasih kepada Rektor, Wakil Rektor, pengelola JPI, penulis, dan semua pihak yang telah mendukung penerbitan perdana JPI. Semoga dengan diterbitkannya JPI ini dapat menjadi media untuk menulis para pustakawan, dosen, guru, dan praktisi dalam bidang iptek dan seni. Ucapan terima kasih juga diucapkan kepada percetakan Yuma Pressindo yang telah membantu mempersiapkan dari awal sampai terbitnya JPI ini. Akhirnya, semoga JPI dapat memberikan nilai kemaslahatan untuk umat.

“Berdiri kemudian berbaring sangatlah cepat tetapi tatkala sudah dituliskan akan menjadi kenangan yang taidak terlupakan sepanjang hayat”

Surakarta, Desember 2015 


\section{DAFTAR ISI \\ JURNAL PUSTAKA ILMIAH EDISI 1 VOLUME 1 TAHUN 2015}

Simbiosis Mutualisme Perpustakaan dengan Media Cetak sebagai Upaya Membudayakan Membaca dan Menulis bagi Masyrakat

Muhammad Rohmadi

Faktor Pengembangan dan Isu dalam Masalah Karier Pustakawan.

Masriyatun

Menguak Informasi via Alexa.com sebagai Evaluasi Menuju Optimalisasi Keberaksesan terhadap Perpustakaan dan Institusinya

Wiji Suwarno

Profesionalisme Pustakawan dalam Layanan Informasi

Sri Anawati

Public Space dan Private Space: Posisi Strategis Perpustakaan dalam Mendukung Pembelajaran Kolaboratif

Purwani Istiana

Mewujudkan World-class Professionalism of Librarians di Era Library Mobile

Yuni Nurjanah

Tantangan dan Kesiapan Pustakawan di Era Digital

Dian Hapsari

Formulasi Strategi Membangun Eksistensi Perpustakaan Perguruan Tinggi (Studi UPT Perpustakaan UNS Tahun 2015)

Riah Wiratningsih

Optimalisasi Perpustakaan Desa dalam Rangka Meningkatkan Pendidikan Masyarakat Bambang Hemanto

Optimalisasi Layanan Perpustakaan Perguruan Tinggi melalui Pemanfaatan Social Media Networking sebagai Media Komunikasi antara Perpustakaan dan Pemustaka Haryanto 


\title{
SIMBIOSIS MUTUALISME PERPUSTAKAAN DENGAN MEDIA CETAK SEBAGAI UPAYA MEMBUDAYAKAN MEMBACA DAN MENULIS BAGI MASYRAKAT
}

\author{
Muhammad Rohmadi \\ Dosen Prodi Pendidikan Bahasa Indonesia FKIP \\ dan Kepala UPT Perpustakaan Universitas Sebelas Maret Surakarta \\ Email:rohmadi_dbe@yahoo.com/081391423540
}

\begin{abstract}
Abstrack
Library and print media as a medium for the dissemination of information and knowledge resource centers. Both the media must have the positive integration of mutual benefit. It is a form of strengthening the various models of information disseminated directly and indirectly. Various models of literacy and knowledge appeared in the print media and it is presented in the library. Therefore, it is necessary to unify the vision synergistic effort between the library and print media so that it can occur symbiotic mutualism between the library and the print media in a variety of contexts of science and technology and the arts. Key words: symbiotic mutualism, libraries, print media, reading, and writing.
\end{abstract}

\begin{abstract}
Abstrak
Perpustakaan dan media cetak sebagai media penyebaran informasi dan pusat sumber ilmu pengetahuan. Kedua media tersebut harus memilki integrasi positif yang saling menguntungkan. Hal ini sebagai bentuk penguatan berbagai model informasi yang didiseminasikan langsung dan tidak langsung. Berbagai model literasi dan pengetahuan muncul dalam media cetak dan tersajikan di perpustakaan. Oleh karena itu, diperlukan upaya sinergis untuk menyatukan visi antara perpustakan dan media cetak sehingga dapat terjadi simbiosis mutualisme antara perpustakaan dan media cetak dalam berbagai konteks iptek dan seni.
\end{abstract}

Kata kunci: simbiosis mutualisme, perpustakaan, media cetak, membaca, dan menulis.

\section{A. Pendahuluan}

Perpustakan memiliki peran penting sebagai sumber informasi, baik cetak dan noncetak bagi pemustaka. Perpustakaan ada di setiap lembaga pemerintah dan nonpemerintah, baik pendidikan dasar, perguruan tinggi, lembaga, dan badan. Berbicara masalah perpustakaan tentu kita tidak dapat melepaskan dari fungsi media cetak dan online sebagai sumber informasi dan pembelajaran bagi peserta didik dan masyarakat umum.
Selaras dengan kesamaan fungsi perpustakaan dan media cetak adalah menyebarkan informasi, sumber layanan informasi, dan sumber belajar bagi mpeserta didik dan masyarakat. Terkait dengan hal tersebut maka fungsi perpustakaan dan media cetak harus dapat diintegrasikan sebagai bentuk penguatan pusat sumber informasi dan belajar. Selain itu, perpustakaan dan media cetak harus memiliki kerja sama untuk menyebarkan informasi kepada peserta didik dan masyarakat umum. 
Merujuk paparan di atas, dapat diperhatikan dalam Undang-Undang Nomor 43 Tahun 2007 tentang Perpustakaan pada Pasal 1 Ayat (1) menyebutkan bahwa perpustakaan adalah institusi pengelola koleksi karya tulis, karya cetak, dan/atau karya rekam secara profesional dengan sistem yang baku guna memenuhi kebutuhan pendidikan, penelitian, pelestarian, informasi, dan rekreasi para pemustaka. Selanjutnya dijelaskan pada ayat (2) bahwa koleksi perpustakaan adalah semua informasi dalam bentuk karya tulis, karya cetak, dan/atau karya rekam dalam berbagai media yang memunyai nilai pendidikan yang dihimpun, diolah, dan dilayankan. Sementara itu, daya dukung perpustakaan adalah pustakawan. Dengan demikian, perpustakaan memiliki fungsi simbiosis mutualisme natara perpustakaan dengan media cetak sebagai pusat sumber belajar dan informasi bagi seluruh civitas akademika untuk meningkatkan budaya baca bagi masyarakat.

\section{B. Mendekatkan Perpustakaan dengan Masyarakat Pendidikan}

Perpustakaan harus menjadi media pembelajaran masyarakat pendidikan di Indonesia. Hal ini dilihat dari peran penting dan fungsi perpustakan sebagai pusat sumber belajar, koleksi, informasi. Oleh karena itu, perpustakaan harus didekatkan kepada masyarakat pendidikan sebagai upaya untuk meningkatkan kompetensi sumber daya manusia. Terkait dengan hal tersebut, pemberdayaan dan pengembangan sumber daya manusia perpustakaan sebagai pustakawan dan ujung tombak pelayanan perpustakaan harus dioptimalkan. Dengan demikian, kedekatan informasi, lembaga, dan fungsi koleksi serta menginformasikan dapat dijalankan seutuhnya oleh para pustakawan dan staf administrasi di perpustakaan.

Terkait dengan hal tersebut, UU Nomor 43 Tahun 2007 Pasal 1 ayat (8) menyebutkan bahwa pustakawan adalah seseorang yang memiliki kompetensi yang diperoleh melalui pendidikan dan/atau pelatihan kepustakawanan serta memunyai tugas dan tanggung jawab untuk melaksanakan pengelolaaan dan pelayanan perpustakaan. Sementara itu pada ayat (9) pemustaka adalah pengguna perpustakaan, yaitu perseorangan, kelompok orang, masyarakat, atau lembaga yang memanfaatkan fasilitas layanan perpustakaan. Lebih lanjut ayat (10) dijelaskan mengenai bahan perpustakaan adalah semua hasil karya tulis, karya cetak, dan/atau karya rekam. Terkait dengan ini para pemustaka adalah peserta didik di sekolah formal dan nonformal. Dijelaskan lebih lanjut pada ayat (11) bahwa masyarakat adalah setiap orang, kelompok orang atau lembaga yang berdomisili pada suatu wilayah yang memunyai perhatian dan peranan dalam bidang perpustakaan. Merujuk penjelasan di atas, dapat ditegaskan bahwa keberadaan perpustakaan sangat diperlukan oleh pemustaka, peserta didik, dan masyarakat umum sebagai sumber ilmu dan pengetahuan secara berkelanjutan dan sekaligus sebagai media rekreasi baca di tingkat pusat, provinsi, kabupaten/kota, sekolah, dan masyarakat.

Dengan demikian semua instansi yang memiliki perpustakaan, baik jenjang pendidikan dasar, menengah, dan tinggi, maupun lembaga pemerintah dan nonpemerintah harus mendekatkan perpustakaan dengan masyrakat pendidikan sebagai pusat sumber belajar bagi peserta didik dan masyarakat umum.

\section{Peran Perpustaakan Nasional Republik Indonesia sebagai Rujukan Nasional}

Perpustakaan memiliki aneka referensi, koleksi, dan layanan yang bervariasi. Namun demikian, tidak semua perpustakaan memiliki koleksi lengkap dan layanan yang sesuai dengan harapan para pengunjungnya. Oleh karena itu, pemerintah memfungsikan perpustakaan nasional RI sebagai rujukan nasional sebagai pusat sumber belajar dan informasi bagi 
masyarakat. Dengan demikian, integrasi perpustakaan sebagai sumber informasi bagi peserta didik dan masyarakat umum dapat terealisasi.

Berbicara masalah peran penting perpustakaan sebagai sumber belajar bagi peserta didik dan masyarakat diperlukan simbiosis mutualisme antara perpustakaan dengan media cetak dan perpustakaan nasional RI sebagai rujukan nasional. Selaras dengan pemikiran di atas, Peraturan Pemerintah Republik Indonesia Nomor 24 Tahun 2014 tentang Pelaksanaan Undang-Undang Nomor 43 Tahun 2007 tentang Perpustakaan dijelaskan pada bab I pasal 1 ayat (7) perpustakaan nasional adalah lembaga pemerintah non-kenegaraan yang melaksanakan tugas pemerintah dalam bidang perpustakaan pembina, perpustakaan rujukan, perpustakaan deposit, perpustakaan penelitian, perpustakaan pelestarian, dan pusat jejaring perpustakaan serta berkedudukan di ibukota negara. Kemudian ayat (8) dijelaskan perpustakaan provinsi adalah perpustakaan daerah yang berfungsi sebagai perpustakaan pembina, perpustakaan rujukan, perpustakaan deposit, perpustakaan penelitian, dan perpustakaan pelestarian yang berkedudukan di ibukota provinsi. Lebih lanjut dijelaskan pada ayat (9) perpustakaan kabupaten/kota adalah perpustakaan daerah yang berfungsi sebagai perpustakaan pembina, perpustakaan rujukan, perpustakaan penelitian, dan perpustakaan pelestarian yang berkedudukan di ibukota kabupaten/kota. Merujuk paparan di atas, peran penting perpustakaan nasional sebagai rujukan nasional dan Pembina perpustakaan umum daerah dan pendidikan sangat diperlukan dalam konteks integrasi perpustakaan dengan media cetak sebagai sumber informasi dan sumber belajar bagi peserta didik dengan masyarakat umum.

\section{Masyarakat Harus Cerdas dan Pandai sebagai Modal Dasar Pembangunan}

Kekuatan sebuah bangsa bergantung pada kompetensi sumber daya manusianya. Oleh karena itu, pemerintah berkewajiban untuk mencerdaskan kehidupan bangsa. Selain itu, masyarakat juga berhak untuk menentukan masa depan bangsanya melalui pendidikan. Terkait dengan hal tersebut, dalam bab II bagian kesatu pasal 5 Ayat (1) UU Nomor 43 Tahun 2007 dijelaskan bahwa masyarakat memunyai hak yang sama untuk: (1) memperoleh layanan serta memanfaatkan dan mendayagunakan fasilitas perpustakaan, (2) mengusulkan keanggotaan dewan perpustakaan, (3) mendirikan dan/atau menyelenggarakan perpustakaan, (4) berperan serta dalam pengawasan dan evaluasi terhadap penyelenggaraan perpustakaan. Selanjutnya pada ayat (2) dijelaskan bahwa masyarakat di daerah terpencil, terisolasi, atau terbelakang sebagai akibat faktor geografis berhak memperoleh layanan perpustakaan secara khusus. Sementara itu, pada ayat (3) dijelaskan bahwa masyarakat yang memiliki cacat dan/atau kelainan fisik, emosional, mental, intelekstual, dan/atau sosial berhak memperoleh layanan perpustakaan yang disesuaikan dengan kemampuan dan keterbatasan masingmasing. Dengan demikian, peran penting pemerintah adalah mengoptimalkan kinerja para pustakawan dan melengkapi sarana dan prasarana yang dimiliki untuk meningkatkan kompetensi sumber daya manusia melalui pustaka ilmiah.

Merujuk paparan tersebut, antara hak dan kewajiban masyarakat terhadap perpustakaan perlu diimbangkan, maka perlu dijelaskan mengenai kewajiban masyarakat. Berdasarkan UU Nomor 43 Tahun 2007 pasa 6 ayat (1) dijelaskan bahwa masyarakat berkewajiban: (1) menjaga dan memelihara kelestarian koleksi perpustakaan, (2) menyimpan, merawat, dan melestarikan naskah kuno yang dimilikinya dan mendaftarkannya ke perpustakaan nasional, (3) 
menjaga kelestarian dan keselamatan sumber daya perpustakaan di lingkungannya, (4) mendukung upaya penyediaan fasilitas layanan perpustakaan di lingkungannya, (5) mematuhi seluruh ketentuan dan peraturan dalam pemanfaatan fasilitas perpustakaan, dan (6) menjaga ketertiban, keamanan, dan kenyamanan lingkungan perpustakaan. Dengan demikian, diperlukan sosialisasi dan pemahaman fungsi perpustakaan kepada masyarakat sebagai sumber belajar dan rekreasi pustaka.

Selaras dengan hal tersebut, pemerintah juga berkewajiban untuk memberikan fasilitas ruang baca kepada seluruh masyarakat. Sesuai dengan ketentuan UU Nomor 43 Tahun 2007 Pasal 7 ayat (1) yang menjelaskan bahwa pemerintah berkewajiban (1) mengembangkan sistem nasional perpustakaan sebagai upaya mendukung sistem pendidikan nasional, (2) menjamin kelangsungan penyelenggaraan dan pengelolaan perpustakaan sebagai pusat sumber belajar masyarakat, (3) menjamin ketersediaan layanan perpustakaan secara merata di tanah air, (4) menjamin ketersediaan keragaman koleksi perpustakaan melalui terjemahan (translasi), alih aksara (transliterasi), alih suara ke tulisan (transkripsi), dan alih media (transmedia), (5) menggalakkan promosi gemar membaca dan memanfaatkan perpustakaan, (6) meningkatkan kualitas dan kuantitas koleksi perpustakaan, (7) membina dan mengembangkan kompetensi profesionalitas pustakawan, dan tenaga teknis perpustakaan, (8) mengembangkan perpustakaan secara berkelanjutan.

Selaras dengan paparan tersebut, sesuai dengan pasal 8 UU Nomor 43 Tahun 2007 dijelaskan bahwa pemerintah provinsi dan pemerintah kabupaten/kota berkewajiban: (1) menjamin penyelenggaraan dan pengembangan perpustakaan di daerah, (2) menjamin ketersediaan layanan perpustakaan secara merata di wilayah masing-masing, (3) menjamin kelangsungan penyelenggaraan dan pengelolaaan perpustakaan sebagai pusat sumber belajar masyarakat, (4) menggalakkan promosi gemar membaca dengan memanfaatkan perpustakaan, (5) memfasilitasi penyelenggaraan perpustakaan di daerah, dan (6) menyelenggarakan dan mengembangkan perpustakaan umum daerah berdasarkan kekhasan daerah sebagai pusat penelitian dan rujukan tentang kekayaan budaya daerah di wilayahnya. Masyrakat Indonesia harus memiliki kecerdasan dan karakter yang kuat (Hidayatullah, 2010; Rohmadi, 2012). Dengan demikian, pemerintah pusat dan daerah harus berkerja sama dalam rangka mepromosikan gemar mebaca bagi peserta didik dan masyarakat sehinga dapat mewujudkan cita-cita masyarakat cerdas dan pandai.

\section{E. Kampanye Budaya Membaca bagi Peserta Didik dan Masyrakat Umum}

Pemerintah melalui lembaga pendidikan negeri dan swasta memiliki kewajiban untuk mengampanyekan budaya membaca bagi peserta didik dan masyrakat umum. Hal ini sebagi upaya peningkatan dan pengembangan kompetensi sumber daya manusia. Hal ini selaras dengan ketentuan UU Nomor 43 Tahun 2007 tentang Perpustakaan dan PP nomor 24 Tahun 2014 tentang Pelaksanaan Undang-Undang Nomor 43 Tahun 2007 tentang Perpustakaan di atas, dapat ditegaskan bahwa pemerintah pusat dan daerah memiliki kewajiban untuk menggalakkan promosi gemar membaca kepada masyarakat, sesuai dengan pasal 7 ayat E menggalakkan promosi gemar membaca dan memanfaatkan perpustakaan. Oleh karena itu, pemerintah berkewajiban untuk menyediakan ruang baca bagi masyarakat umum dalam bentuk perpustakaan umum daerah yang dapat dijangkau dengan berbagai fasilitas pendukung dan koleksi yang dapat menjadi sumber bacaan, penelitian, dan juga pengembangan diri secara berkelanjuatan. Hal ini menjadi kewajiban bersama antarpemerintah dan masyarakat untuk memeliharanya. 
Integrasi dan simbiosis mutualisme antara pemerintah pusat, daerah, perguruan tinggi, sekolah, dan pemerintah desa untuk menggagas dan mempromosikan perpustakaan sebagai pusat sumber belajar dan informasi bagi peserta didik dan masyarakat sangatlah diperlukan saat ini. Dengan demikian, upaya pemerintah untuk mencerdaskan kehidupan bangsa sesuai dengan amanah UUD 1945 akan dapat segera tercapai dengan secara bertahap pada semua elemen masyarakat, baik secara formal maupun nonformal. Oleh karena itu, seluruh masyarakat pendidikan memiliki kewajiban untuk mengkapanyekan gemar membaca bagi peserta didik dan masyarakat umum.

\section{F. Kewajiban Pemerintah untuk Mencerdaskan Kehidupan Bangsa}

Dalam rangka mencerdaskan kehidupan bangsa, pemerintah memiliki kewajiban sesuai ketentuan undang-undang. Terkait dengan ini, maka pemerintah juga berkewajiban untuk memberikan fasilitas ruang baca kepada seluruh masyarakat. Hal ini selaras dengan ketentuan UU no. 43 tahun 2007 pasal 7 ayat (1) yang menjelaskan bahwa pemerintah berkewajiban (1) mengembangkan sistem nasional perpustakaan sebagai upaya mendukung sistem pendidikan nasional, (2) menjamin kelangsungan penyelenggaraan dan pengelolaan perpustakaan sebagai pusat sumber belajar, (3) menjamin ketersediaan layanan perpustakaan secara merata di tanah air, (4) menjamin ketersediaan keragaman koleksi perpustakaan melalui terjemahan (translasi), alih aksara (transliterasi), alih suara ke tulisan (transkripsi), dan alih media (transmedia), (5) menggalakkan promosi gemar membaca dan memanfaatkan perpustakaan, (6) meningkatkan kualitas dan kuantitas koleksi perpustakaan, (7) membina dan mengembangkan kompetensi profesionalitas pustakawan, dan tenaga teknis perpustakaan, (h) mengembangkan perpustakaan secara berkelanjutan.
Sementara itu, pemerintah provinsi dan kabupaten juga memiliki kewajiban yang sama. Hal ini dapat dijelaskan sesuai pasal 8 UU No. 43 tahun 2007 dijelaskan bahwa pemerintah provinsi dan pemerintah kabupaten/kota berkewajiban; (1) menjamin penyelenggaraan dan pengembangan perpustakaan di daerah, (2) menjamin ketersediaan layanan perpustakaan secara merata di wilayah masing-masing, (3) menjamin kelangsungan penyelenggaraan dan pengelolaan perpustakaan sebagai pusat sumber belajar masyarakat, (4) menggalakkan promosi gemar membaca dengan memanfaatkan perpustakaan, (5) memfasilitasi penyelenggaraan perpustakaan di daerah, dan (6) menyelenggarakan dan mengembangkan perpustakaan umum daerah berdasarkan kekhasan daerah sebagai pusat penelitian dan rujukan tentang kekayaan budaya daerah di wilayahnya.

Berdasarkan paparan dari ketentuan UU No. 43 tahun 2007 tentang perpustakaan dan PP no. 24 tahun 2014 tentang pelaksanaan undangundang no. 43 tahun 2007 tentang perpustakaan di atas dapat ditegaskan bahwa pemerintah pusat dan daerah memiliki kewajiban untuk menggalakkan promosi gemar membaca kepada masyarakat, sesuai dengan pasa 7 Ayat E. Oleh karena itu, pemerintah berkewajiban untuk menyediakan ruang baca bagi masyarakat umum dalam bentuk perpustakaan umum daerah yang dapat dijangkau dengan berbagai fasilitas pendukung dan koleksi yang dapat menjadi sumber bacaan, penelitian, dan juga pengembangan diri secaraberkelanjuatan. Halini menjadi kewajiban bersama antara pemerintah dan masyarakat untuk memeliharanya.

Pemerintah sangat berperan dalam pengembangan minat baca. Sesungguhnya, pengembangan minat baca di sekolah, di masyarakat, dan di keluarga tidak bisa terlepas dari peran pemerintah, baik pemerintah pusat maupun pemerintah daerah. Dengan adanya otonomi daerah, peran pemerintah 
daerah, khususnya pemerintah kabupaten atau pemerintah kota, lebih dominan dari pemerintah pusat. Hal ini disebabkan karena kewenangan di bidang pendidikan ada pada pemerintah daerah.

Peran pemerintah dalam pengembangan minat baca di sekolah terutama terlihat dari sejauh mana komitmen pemerintah dalam pengadaan buku-buku atau koleksi perpustakaan sekolah. Tersedianya buku-buku yang menarik dan sesuai dengan kebutuhan siswa yang memadai di perpustakaan sekolah akan mendorong tumbuhnya minat baca siswa. Sebagaimana telah diuraikan pada bagian 3.1, tersedianya buku-buku atau bahan bacaan yang menarik dan sesuai dengan kebutuhan siswa merupakan salah satu prinsip dalam pengembangan minat baca.

Kenyataan menunjukkan bahwa secara umum, keadaan perpustakaan sekolah sangat mengkhawatirkan. Kendala utama yang dihadapi adalah pengadaan koleksi. Di samping itu, perpustakaan sekolah juga mengalami kendala dalam pengelolaan. Lebihlebih perpustakaan sekolah di SD yang tidak memiliki tenaga khusus. Kendala pengadaan koleksi perpustakaan biasanya dikaitkan dengan terbatasnya dana pendidikan. Dengan adanya komitmen pemerintah untuk menaikkan anggaran pendidikan, mudahan-mudahan kendala pengadaan buku perpustakaan sekolah bisa diminimalkan dan bisa berkurang.

Untuk meningkatkan minat baca, pemerintah daerah perlu mengaktifkan perpustakaan keliling. Sebagaimana diketahui, secara demografi, penduduk kita kebanyakan tinggal di desa-desa dan pedesaan yang jauh dari kota-kota kabupaten yang biasanya juga memiliki perpustakaan daerah masing-masing. Oleh karena itu, cara yang sangat strategis untuk meningkatkan minat baca ini adalah dengan perpustakaan keliling. Dalam hal ini, perpustakaan memberikan pelayanan secara berkala kepada masyarakat ke desa-desa. Hal ini tampaknya sulit dilakukan karena krisis multidimensional belum teratasi. Setidaktidaknya, mengaktifkan perpustakaan keliling perlu menjadi pemikiran dan perhatian pemerintah daerah ke depan.

\section{G. Strategi Meningkatkan Budaya Baca bagi Masyarakat}

Pentingnya minat baca masyarakat mempertegas upaya memperkuat kemampuan baca seseorang dengan banyak upaya strategis. Sudiana (2004: 103) menyatakan bahwa orang yang memiliki minat baca yang tinggi akan sering melakukan kegiatan membaca. Dengan seringnya membaca, akan terpupuk kebiasaan membaca. Baginya, membaca dirasakan sebagai suatu pemenuhan kebutuhan. Orang yang demikian akan menganggap membaca koran pagi, misalnya, sebagai sarapan. Dengan memiliki kebiasaan membaca yang tinggi, orang akan merasa ketagihan membaca. Oleh karena itu, untuk membudayakan membaca di kalangan masyarakat, khususnya kaum pelajar, pengembangan minat baca perlu mendapat perhatian yang sungguh-sungguh. Mastini Hardjoprakosa (2005 : 145) juga mengutarakan tentang beberapa faktor yang menyebabkan rendahnya minat baca masyarakat di Indonesia antara lain : (a) pemerintah dan swasta dengan lembaga pendidikannya, para guru kurang memotivasi para anak didiknya untuk membaca buku-buku selain buku pelajaran, (b) para orang tua tidak memberi dorongan kepada anak untuk mengutamakan membeli buku dari pada mainan, alat pandang dengar. Mereka biasanya kurang mengetahui jenis buku yang sesuai dan disukai anak, dan mereka biasanya juga kurang memperkenalkan perpustakan kepada anakanak, (c) para penerbit media cetak memasang harga buku yang bermutu terlalu tinggi, sehingga tak terjangkau oleh masyarakat luas, (d) para pengarang, penyadur dan penerjemah yang semakin berkurang, karena royalti yang tidak menentu dan masih terkena PPH, (e) perpustakaan Umum yang jumlahnya belum 
mencukupi di tiap Propinsi untuk melayani masyarakat, dan (f) perpustakaan masjid yang belum terkelola dengan profesional.

Disadari atau tidak kemampuan membaca masyarakat Indonesi sangat rendah. Hal ini selaras dengan penjelasan Baderi (2005) bahwa kemampuan membaca (Reading Literacy) anak-anak Indonesia sangat rendah bila dibandingkan dengan negara-negara berkembang lainnya, bahkan dalam kawasan ASEAN sekali pun. International Association for Evaluation of Educational (IEA) pada tahun 1992 dalam sebuah studi kemampuan membaca murid-murid Sekolah Dasar Kelas IV pada 30 negara di dunia, menyimpulkan bahwa Indonesia menempati urutan ke-29 setingkat di atas Venezuela yang menempati peringkat terakhir pada urutan ke-30. Data di atas relevan dengan hasil studi dari Vincent Greannary yang dikutip oleh Worl Bank dalam sebuah Laporan Pendidikan "Education in Indonesia From Cricis to Recovery" tahun 1998. Hasil studi tersebut menunjukkan bahwa kemampuan membaca anak-anak kelas VI Sekolah Dasar meraih kedudukan paling akhir dengan nilai 51,7 setelah Filipina yang memperoleh nilai 52,6; Thailand dengan nilai 65,1; serta Singapura dengan nilai 74,0; dan Hongkong yang memperoleh nilai 75.5. Merujuk paparan tersebut, menjadi pekerjaan rumah bagi seluruh guru, dosen, dan masyarakat pendidikan untuk meningkatkan budaya baca peserta didik dan masyarakat umum.

Kondisi lemahnya kemampuan membaca anak-anak Indonesia sebagaimana data di atas berdampak pada kekurangmampuan mereka dalam penguasan bidang ilmu pengetahuan dan matematika. Hal ini dapat dilihat dari hasil tes yang dilakukan oleh Trends in International Mathematies and Science Study (TIMSS) tahun 2003 pada 50 negara di dunia terhadap para siswa kelas II SLTP, menunjukkan prestasi siswa-siswa Indonesia hanya mampu meraih peringkat ke-34 dalam kemampuan bidang matematika dengan nilai 411 di bawah nilai rata-rata internasional yang 467. Sementara itu, hasil tes bidang ilmu pengetahuan mereka hanya mampu menduduki peringkat ke-36 dengan nilai 420 di bawah nilai rata-rata internasioal 474. Dibandingkan dengan anak-anak Malaysia mereka telah berhasil menduduki peringkat ke 10 dalam kemampuan bidang matematika yang memperoleh nilai 508 di atas nilai rata-rata internasional. Dan dalam bidang ilmu pengetahuan mereka menduduki peringkat ke-20 dengan nilai 510 di atas nilai rata-rata internasional. Dengan demikian tampak jelas bahwa kecerdasan bangsa kita jauh tertinggal di bawah negaranegara berkembang lainnya. Oleh karena itu, kita semua berkwajiban bekerja sama untuk meningkatkan kompetensi sumber daya manusia Indonesia seutuhnya.

Kita perlu melihat dan melakukan tindakan nyata dengan kondisi minat baca masyarakat Indonesia yang rendah. Hal ini sangat selaras dengan United Nations Development Programme (UNDP) yang menjadikan angka buta huruf dewasa (adult illiteracy rate) sebagai suatu barometer dalam mengukur kualitas suatu bangsa. Tinggi rendahnya angka buta huruf akan menentukan pula tinggi rendahnya Indeks Pembangunan Manusia (Human Development Index-HDI) bangsa itu. Berdasarkan laporan UNDP tahun 2003 dalam "Human Development Report 2003" bahwa Indeks Pembangunan Manusia (Human Development Indeks-HDI) berdasarkan angka buta huruf menunjukkan bahwa "pembangunan manusia di Indonesia" menempati urutan yang ke-112 dari 174 negara di dunia yang dievaluasi. Sedangkan Vietnam menempati urutan ke-109, padahal negara itu baru saja keluar dari konflik politik yang cukup besar. Namun negara mereka lebih yakin bahwa dengan "membangun manusianya" sebagai prioritas terdepan, akan mampu mengejar ketinggalan yang selama ini mereka alami. 
Dengan demikian, peran penting pendidikan dasar, menengah, dan tinggi sangat dibutuhkan untuk meningkatkan kualitas manusia Indonesia.

Merujuk hasil studi di atas dan laporan United Nations Development Programme (UNDP) maka dapat diambil simpulan (hipotesis) bahwa “ kekurangmampuan anakanak kita dalam bidang matematika dan bidang ilmu pengetahuan, serta tingginya angka buta huruf dewasa (adult illiteracy rate) di Indonesia adalah akibat membaca belum menjadi kebutuhan hidup dan belum menjadi budaya bangsa. Oleh sebab itu, membaca harus dijadikan kebutuhan hidup dan budaya bangsa kita. Mengingat membaca merupakan suatu bentuk kegiatan budaya menurut H.A.R Tilaar (1999: 381) maka untuk mengubah perilaku masyarakat gemar membaca membutuhkan suatu perubahan budaya atau perubahan tingkah laku dari anggota masyarakat kita. Dengan demikian, mengkampanyekan budaya baca dan optimalisasi perpustakaan sebagai sumber belajar dan layanan informasi bagi peserta didik dan masyarakat sangat diperlukan.

\section{H. Simbiosis Mutualisme Perpustakaan dengan Media Cetak dan Online}

Perkembangan zaman dan teknologi telah mempengaruhi budaya baca masyarakat. Budaya baca masyarakat pendidikan yang dulu di perpustakaan sekarang sudah banyak yang beralih ke e-paper. Namun demikian, bukan berate perpustakaan ditinggalkan oleh para pemustaka. Justru disinilah yang harus dilakukan oleh pemerintah dan pengelola perpustakaan untuk melalukan simbiosis mutualisme antara perpustakaan dengan media cetak dan online.

Peprustakaan harus menjadi pusat layanan informasi yang terintegrasi dengan media cetak dan online. Dengan demikian, melalu pengembangan sistem teknologi dan informasi yang terintgegrasi dapat memberikan cerminan bagaiman pemanfaatan teknologi dalam rangka peningkatan budaya baca. Terkait dengan hal tersebut, berbagai informasi yang tertuang dalam buku, media cetak, dan online dapat dibaca dan dinikmati oleh para pembaca di ruang perpustakaan atau di mana pun para pembaca berada.

Simbiosis mutualisme antara perpustakaan dengan media cetak dan online sangat diperlukan dalam rangka memberikan layanan prima dan kinerja yang unggul bagai pengelola perpustakaan dan seluruh pembaca. Oleh karena itu, sangat diperlukan pengkondisian dan pembiasan membaca berbasis media cetak dan online di perpustakaan. Dengan rajin membaca maka akan dapat memberikan pengembangan wawasan keilmuan dan pengetahuan bagi masyarakat Indonesia. Dengan demikian akan lahir generasi-generasi muda yang cerdas, terampil, dan berwawasan sangat luas dnegan membaca.

\section{Penutup}

Berdasarkan paparan di atas, dapat ditegaskan pemerintah memiliki kewajiban untuk mencerdaskan kehidupan bangsa. Sementara itu, masyarakat memiliki hak untuk mendapatkan pendidikan dari pemerintah. Oleh karena itu, diperlukan upaya bersama antara pemerintah dan masyarakat untuk mewujudkan pendidikan untuk semua. Terkait dengan hal tersebut, kewajiban seluruh elemen pendidikan formal dan nonformal melalu perpustakaan sekolah, desa, masjid, perpustakaan umum/ daerah, perpustakaan perguruan tinggi di seluruh wilayah Indonesia harus terintegrasi untuk menjadikan perpustakaan sebagai pusat sumber belajar bagi masyarakat, dalam rangka mewujudkan secara periodik dan cepat untuk mencerdaskan kehidupan bangsa Indonesia. Selamat belajar, membaca, untuk menyibak jendela dunia demi kemajuan dan kejayaan pendidikan untuk masyarakat Indonesia. 


\section{Daftar Pustaka}

Baderi, Athaillah (2005), Kiat dan Strategi Meningkat Minat Baca Masyarakat; Teknis perpustakaan sekretariat Jenderal Departemen Dalam Negeri, Jakarta ; Departemen Dalam Negeri.

Hidayatullah, Furqon. 2010. Pendidikan Karakter: Membangun Peradaban Bangsa. Surakarta: Yuma Pustaka.

Permendikbud. 2015. “Permendikbud No. 21/Tahun 2015” mengenai kewajiban membaca bagi siswa sebelum pembelajaran dimulai". Jakarta: Kemendikbud.

Rohmadi, M. 2012. Menjadi Guru Profesional dan Berkarakater. Surakarta: Yuma Pustaka.

Rohmadi, M. 2015. "Menjadi Pustakawan yang Andal dan Profesional" dimuat di Solopos, 30 September 2015.

Rohmadi, M. 2015. “Optimalisasi Perpustakaan sebagai Sarana Pengembangan Budaya Membaca dan Menulis dalam Rangka Meningkatkan Kompetensi Sumber Daya Manusia yang Unggul dan Kreatif' Prosiding, Seminar Nasional yang diselenggarakan oleh Perpustakaan UNS.

Undang-undang Republik Indonesia No. 43 Tahun 2007 tentang Perpustakaan.

Widyono, Hanputro. 2015. “"Menunggu Warisan Budaya Membaca” dimuat pada Rubrik Mimbar Mahasiswa Solopos, tanggal 11 Agustus 2015.

Sudiana, I Nyoman. 2004. "Pengembangan Minat Baca di Daerah" Jurnal Pendidikan dan Pengajaran No.2 tahun XXXVII halaman 100-113. 